\title{
IMPACT OF CLIMATE CHANGE ON SUGARCANE CROP AND REMEDIAL MEASURES-A REVIEW
}

\author{
Muhammad Chohan \\ National Sugar and Tropical Horticultural Research Institute, Thatta
}

\section{ABSTRACT}

Increasing demand of bioenergy, sugar and other byproducts make sugarcane (Sacharum officinarum) very important and valuable crop in world. It is growing on the many diversified agroecological zones of 120 countries of the world. Brazil, India, China, Thailand, Pakistan, Mexico, Colombia, Indonesia, Philippines, and USA (number wise from area and production) are top ten sugarcane producing countries in the world. But yield production per hectare of these countries is ranged from 56-86 $\mathrm{t} \mathrm{ha}^{-1}$ is much lower than the achievable potential 100-130 $\mathrm{t} \mathrm{ha}^{-1}$. Amongst many other factors responsible for lowering the yield, change in environment is now growing a major factor. It is very difficult to increase area for sugarcane, so efforts are made to increase the yield production at the same cultivated area, the per hectare yield production must be improved by adapting modern technologies suited for changing environment. The global warming is increasing due to change in environment by the increasing emission of greenhouse gases. Sugarcane is sensitive for climatic parameters such as temperature, rainfall, sunlight and soil. The research indicated that global temperature will be increased from $3-5^{\circ} \mathrm{C}$ in the end of $21^{\text {st }}$ century. The enormous human activities are causing to accelerate the changing in our ecosystem with low or high rainfall, temperature, severity of pests pressure, unavailability of pollination services, decrease soil fertility, alter the water use efficiencies and crop behavior. Changes in temperature, rainfall, floods, drought, salinity stresses and frosts have been found major factor for lowering production of sugarcane in Pakistan is highly dependent on natural resources. Obtaining the high cane production with high quality juice in future, it is necessary to develop cane varieties and advanced farm management practices which will suitable under changing environment.

\section{INTRODUCTION}

Sugarcane

(Saccharum

officinarum $L$ ) is the gaint prerenial $\mathrm{C}_{4}$ crop, growing throughout the world and providing about $75 \%$ of sugar for human consumption (Souza et. al., 2008). It is very important crop for sugar, bioenergy and other valuable byproducts. The average cane and sugar yield is much lower than the achievable potential of the crop. Area wise, Brazil is the highest, 5.63 million ha, India 4.0 million ha and Pakistan contributes one million hectares. In production, Brazil still remains on the top with $33 \%$ of global sugar production followed India (23\%), China (7\%) and Pakistan (4\%) (FNP, 2009). There are number of reasons for lower cane and sugar yield one of those the climate change is a boosting major factor now days. The climate change is reason by natural processes and anthropogenic factors may results major environmental issue that will have continuously affect on yield and production of agricultural crops. Variability in climatic conditions could bring the changes in sea levels, temperature, rainfall, droughts, floods, tornados, hurricanes and abiotic stresses. It is generally believed that global warming is due increasing $\mathrm{CO}_{2}$ concentrations and other greenhouse gasess (GHG) in our atmosphere. It is estimated that $\mathrm{CO}_{2}$ concentrations has been increased by about $30 \%$ since $18^{\text {th }}$ century, caused by increase in combustion of fossils fuel, industrial processes and deforestation (Zhao and Yang, 2015). The mean global temperature had increased from 0.55 to $0.67^{\circ} \mathrm{C}$ in the last century and are project to rise from 1.1 to $2.9^{\circ} \mathrm{C}$ (Low emission) or 2.0 to $5.4^{\circ} \mathrm{C}$ (high emission) by 2100 relative to 1980-1999. The 
low and high emission would caused by increase in atmospheric $\mathrm{CO}_{2}$ at 550 and 800 ppm respectively from current levels by end of 2100 century (2). It is revealed that temperature in Pakistan rose from 0.3 to $0.8^{\circ} \mathrm{C}$ during last century (Afghan 2014). The increase in temperature could be beneficial for some crops like $\mathrm{C}_{3}$ plants and sugarcane in the some parts of the world. Climate variability and change are projected to result in changes in the frequency of extreme high temperature events, floods and droughts (Trenberth et. al., 2007). Changing in climate will bring the change in our ecosystem with low or high rainfall, temperature, Advance agronomic measures

including development of suitable sugarcane varieties, time and methods of planting, soil preparation, management of insect pest diseases, nutrients and water management, weed eradication, are seems to be very promise measures for obtaining high sugarcane production. verity of pests pressure, unavailability of pollination servi Advance agronomic measures including development of suitable sugarcane varieties, time and methods of planting, soil preparation, management of insect pest diseases, nutrients and water management, weed eradication, are seems to be very promise measures for obtaining high sugarcane production decrease soil fertility, alter the water use efficiencies and crop behavior that effect the agricultural crops. Changes in temperature and rainfall, drought stresses and frosts have been found major factor for lowering production of sugarcane in Pakistan is highly dependent on natural resources. The end products of sugarcane are sugar and ethanol have a continuous growing demand on world level. So it is very important to studies related for good production of sugarcane in changing of climatic conditions has become one among the front line area of research. Advance agronomic measures including development of suitable sugarcane varieties, time and methods of planting, soil preparation, management of insect pest diseases, nutrients and water management, weed eradication, are seems to be very promise measures for obtaining high sugarcane production.

\section{Top ten Sugar producer country}

Sugarcane production was increased four times higher from 1965 (531.3 million tons) to 2014. Worldwide sugarcane occupies an area of 20.42 million ha with a total production of 1328 million metric tons from which about 145 million tons of sugar is manufactured per year. The increasing demand of bio-fuel energy it is very difficult to increase the area for sugarcane. So there will be focus on increase the yield tons per hectare in future. During the year 2015 the sugar production was remain
170.911 million tones, against the consumption of 173.398 million tons. The annual consumption is increased from 2 million tons to 2.487 million tones PSMA, (2015). Brazil, India, China, Thailand, Pakistan, Mexico, Colombia, Indonesia, Philippines, and USA are top ten sugarcane producing countries in the world. From the area and yield production Brazil is on top in world followed by India and respectively. The yield production in tons per hactares ranked these countries as 29th, 40th, 39th, 26th, 51, 25th, 19th, 31st, 37th, and 27th, respectively, in the 103 sugarcane producing countries of world (Factfish-2015, FAO2014). Peru, Ethiopia, Egypt and Senegal are top countries in the world which produces upto 135.92, 129.57, 121.34 and 116.84 respectively sugarcane yield $\mathrm{t} \mathrm{ha}^{-1}$ while the top ten countries are ranged from 50 to $80 \mathrm{t} \mathrm{ha}^{-1}$ is much lower than many other countries of world. Though sugarcane in above countries is not growing on vast area and ranked 18, 43, 16 and 57 respectively in sugarcane production in world, but some parts of the said countries have suitable soil and environment conditions for proper sugarcane production. In last 41 years (1973-2013) the sugarcane production was increased linearly in all the seven top countries. During the 2015 year sugar production decreased by $9 \%$ in Pakistan because of marginal decrease in area and sugarcane production as compared to 2013-14. The sugar production in India was also decreased by 2 million 
tones for the year of 2015-16 due to poor rainfall (PSMA2015). In Pakistan sugarcane hectarage and cane yield were increases in similar proportion. But in the other countries the increase in area was remain major contributor than increase in cane yield. The yield production (58\%) and hectrages (57 \%) were increased in Pakistan in last 41 years (1973-2013). While in other top countries like Brazil, India, China, Thailand, Mexico, and Colombia the hecterage was increased by 500, 94 , $237,286,52$, and $61 \%$ respectively and cane yields was increased by $60,38,59$, 70,11 , and $24 \%$, respectively. In the same period of years, sugarcane hectarage in USA increased only $31 \%$ and yield had no big change or slightly decreased $(7.0 \%)$ (Factfish, 2015). The per hectares yield production of world was increased $9.55 \%$ from 2000 to 2013 while from 1961 to 2013 the yield was increased 41.11 $\%$ per hectare. The yield production per hectare of the world was remained high (71.13-71.71 tons $\mathrm{ha}^{-1}$ ) in the period of 2007 to 2010 than period of 1961 to 2006 and 2011 to 2013.

\section{Sugarcane in Pakistan}

In Pakistan sugarcane is cultivated under many diversified agro ecological conditions. The sugarcane is grown on above than 1million hectares with total production of 63.75 million tons, ranks Pakistan at fifth number in world. The yield 56.48 tons ha${ }^{1}$ ranks Pakistan at 51 number in world. From the acreage Punjab is on top $(60-65 \%)$ followed by Sindh (25-30\%) and KPK (8-10\%) of total area of country. The average cane yield tons per hectare of Sindh province is better than Punjab and KPK, therefore share of Sindh in total sugar production is about $40 \%$ (FAO, 2015). This may be due to differences in planting method, management practices, environmental conditions and differences in cultivation season. In Sindh most planting is done in autumn season, due to long season the crop allowing to remain 14-18 months in the field to achieve its full maturity, while in other provinces the cultivation of sugarcane is started in months of spring and remained 12-14 months in field. The yield production per hectares in Sindh was decreased (9-15\%) from $63.0 \mathrm{t} \mathrm{ha}^{-1}$ in 2012-13 to $52.42 \mathrm{t} \mathrm{ha}^{-1}$ in 2014-15 and sugar recovery (9.23-10.53) was increased by $14.08 \%$ in the period of last 15 years. In Punjab the yields were relatively remained constant at $47.96 \mathrm{t} \mathrm{ha}^{-1}$ for last 10 years, now in the last five years it rising from 55.75 to $57.80 \mathrm{t} \mathrm{ha}^{-1}$ for $2010-2011$ and 2014-2015 while the sugar recovery (7.56-9.9 \%) of the province was significantly increased (24.37 \%) Punjab during last 15 years. The decline in yield might be due to frost conditions in northwest parts of Punjab province and salinity problems in southern parts of Sindh, where the sugarcane is growing on vast a sugarcane area with yield of $35-40 \mathrm{t} \mathrm{ha}^{-1}$ is much lower than the other parts of provinces. Some growers of Punjab and Sindh provinces obtained the yield production upto $120 \mathrm{t} \mathrm{ha}^{-1}$.

\section{Major constraints in country}

There are about 60 factors are found cause to decline yield production of sugarcane in country. Some major factors are:

Water: Water is the major constraint of decline of sugarcane yield production in country Punjab y. Sugarcane requires the larger quantity of irrigation water than the other crops to reach its maturity. The average rainfall in Punjab is about $335 \mathrm{ml}$ per year and in Sindh the conditions are very crucial that annual rainfall is limited and even low than Punjab. Drought is a major abiotic stress that affects crop productivity and exerts some visible symptoms on sugarcane (Begcy et. al., 2012 and Malik et. al., 1992). Pakistan once was a water surplus country, and now a day it is water deficit country. The rainfall is neither sufficient nor regular, to meet the water requirement for growing a crops. About 70 per cent of the annual rainfall occurs in the months of July to September and also a peak water flow period. The surface water resources of Pakistan mainly consist of flows of the Indus River (65\% share) and its tributaries, which bring in about 138 million acre feet (MAF) of water annually. From total available resource of water about $33 \%$ water is lost due to seapages from main canals, distributaries, tinny channels and misused by farmers. Total demand with losses was about 188.28 MAF 
in 2000 and it will increased upto 261.14 MAF for 2025. The water development potential for main sugarcane produced provinces about 0.78 MAF for Sindh and 2.7 MAF of Punjab is lowest as compared to other two provinces Baluchistan and KPK (7.86 MAF) (Akram et. al., 2013). Scarcity of water in the country is mostly occurs in the months from November to April because of low rainfall and cold weather (slow down to melting of glacier). The formative and elongation phases of sugarcane growth have been identified as a critical water demand period. During scarcity of irrigation water in said months the formation and elongation phases of autumn planted sugarcane and formative phase of spring season crop starts and requires more irrigation water. When drought occurs, the crop experiences slow growth, which subsequently results in low cane yield (Barnes, 1974). As stalk population and stalk growth are reduced, resulting in $30-50 \%$ yield loss (Silva et. al., 2007).

Variety: The next major constraint is unavailability of new high yield frost free, tolerant to salinity and drought and resistant to insect pest diseases varieties. The majority of the varieties developed in abroad are adapted in the country have deteriorated yield and sugar recovery. Some sugarcane varieties are developed through fuzz are very promising in the different agroecological parts of country. The varieties developed through fuzz like Th-10, Thatta-326, Thatta-2109 and Thatta-300 are growing on vast area of Sindh and some parts of Punjab province showed good performance. It is estimated that in areas where the varieties are growing on major scale, the yield production of farmers and sugar recovery of mills is significantly rising. On the other hand the some adapted varieties are found to be the diseases cause like red rot, pokha, mealy bug, whitefly etc. The said disease were not common in the country since from 1961 , but now cause to decline of yield production considerably in Sindh province as well as in country.

Soil: Sugarcane is annual exhaustive crop yield depends on the available nutrient status of the soil (Khan et. al., 2009). It has been reported that soils of Pakistan are alkaline calcareous in nature, heavy in texture, almost 100\% deficient in N, 90\% deficient in $\mathrm{P}, 20$ to $40 \%$ deficient in $\mathrm{K}$ while organic matter is on average $0.5 \%$ only (Wahab, 1985; Rashid, 1996; Shah and Arshad, 2006; Perveen et. al., 2010; Saleem and Akhtar, 2011). Sugarcane is sensitive for salinity and alkalinity of soil. The soils of southern part of country environmentally suitable for high cane yield and sugar recovery than the other parts of country, have high $\mathrm{pH}$ ranges (7.5 to 9.2) and the salinity increasing from level $2.73 \mathrm{dSm}^{-1}$ of sugarcane day by day (Chohan et. al., 2015). Yield production is declined by $50 \%$ under water logging and salinity area, it is estimated that $40 \%$ sugarcane growing areas of country have salinity problem (wwf, 2015).

Policy: Most of The procurement prices for sugarcane is said to be major decline of sugarcane area in country especially in Sindh province. The farmers demanding the minimum support prices above than 52 USA $\$$ tons $^{-1}$ of sugarcane but the government of Punjab and KPK announces at $45 \$$ ton $^{-1}$, and Sindh announced $46 \$$ ton $^{-1}$ (GAIN2015). The high costs of production and low support prices, are found to be negative impact on sugarcane production.

\section{Sugarcane and environment}

Sugar cane is used for the manufacturing of sugar, byproducts and bioenergy. It is grown in hot and humid climate and well adapted in many regions of Pakistan. The yield production is much lower than the other countries of world this is may be possible reduction in rainfall, high frost and drought conditions. Sugarcane is long duration crop, plant stands in the field for 12-24 months, hence, goes through all possible limits of weather parameters i.e. rainfall, temperature, sunshine, humidity etc (Srivatava and Rai 2012). All these parameters have a role in plant growth, sugar yield, quality and content of juice etc. The impact of climate changes on potential sugar cane yield in Brazil will be negative and potential yield can be reduced in near future (2014-2040). 
High temp. will increase the evapo transpiration rates, reducing the amount of water available in soil, making the planting of sugarcane increasingly difficult, which tend to be strongly reduced in drier areas Carvalhao et. al., (2015). On the other hand Marin et al. (2011) stated that climate change improve water use efficiency in sugarcane (34\%) will increase fresh stalk mass ( $24 \%$ ) in some parts of Brazil and predicted that 15-59 $\%$ higher sugarcane yield than that at current average level will be obtained in 2050 . The cane yield and sugar yield have fluctuated under the drought and tropical cyclone conditions in Fiji. Due to favorable weather a record sugar production (516529 tonnes) was obtained in 1994, but in 1997, 1998 and 2003 there were 47,50 and $43 \%$ sugarcane production was decreased than that of in 1994 due to drought environment Gawander, 2007. Sugarcane yield in Pakistan will be declined due to increased water stress conditions, arising from increasing temperature and reduction of rainy days. Sugarcane yield will decreased (10\%) by increase of $1^{\circ} \mathrm{C}$ temperature and may affect on accumulation of sucrose content Afghan (2014). Sugarcane is very sensitive to temperature, rainfall, solar radiation therefore significant effect on its production and sugar yield is expected in future. (Srivastava and Rai, 2012).

Rainfall: The sugarcane plant requires optimum rains during the vegetative growth for thick and tall cane formation and less during the ripening time for good quality juice. The rain fall ranges from 1100 $1500 \mathrm{~mm}$ is optimum for higher cane yield. It can be grown successfully on the lower levels of $600 \mathrm{~mm}$ rainfall (ICAR 2000).

Temperature: The optimum ranges of temperature varies for different stages of crop, for good germination the temperature will required in between $32-38^{\circ} \mathrm{C}$. Temp. above the $38^{\circ} \mathrm{C}$ it not only reduces the germination but also effect on vegetative growth, due to reduction in photosynthetic rates and increase in respiration. Ripening period, require low temperature in the range of $12-14^{\circ} \mathrm{C}$ reduces vegetative growth rate and enrichment of sucrose in the cane (Fageria, et. al., 2011). Temperature below $5^{\circ} \mathrm{C}$ and above $35^{\circ} \mathrm{C}$, not favorable for young leaves and buds. The high temperature may enhance the diseases and change the sucrose content into fructose and glucose and photorespiration may reduce accumulation of sugar (Binbol et. al., 2006, Gawander 2007).

Sunlight: For formative and grand growth period sunlight intensity is necessary to C4 plants, which has high capacity of photosynthesis as well as stabilization ranges. During the cloudy and short days season tillering of plant is severly affected, while bright sun shine on average 7-9 hours is very beneficial stalk formation and good growth (ICAR 2000; Fageria, et. al.
2010). The proper spacing in between rows is very essential to provide the proper sunlight sugarcane crop, upper six leaves canopy intercept $70 \%$ of the radiation which reduce the photosynthesis rate of lower leaves due to mutual shading. The areas with short growing period benefit from closer spacing to intercept higher amount of solar radiation and thus get higher yields however, with long growing season, wider spacing is suggested to avoid mutual shading and mortality of shoots.

Photosynthesis: The sugar cane growth and formation of sugars mechanisms are depends upon photosynthesis, for which sunlight is required. The growth of plant result from conservation of Sugar cane is used for the manufacturing of sugar, byproducts and bioenergy. It is grown in hot and humid climate and well adapted in many regions of Pakistan. The yield production is much lower than the other countries of world this is may be possible reduction in rainfall, high frost and drought conditions. Sugarcane is long duration crop, plant stands in the field for 12-24 months, hence, goes through all possible limits of weather parameters i.e. rain-fall, temperature, sunshine, humidity etc (Srivatava and Rai 2012). All these parameters have a role in plant growth, sugar yield, quality and content of juice etc. The impact of climate changes on potential sugar cane yield in Brazil will be negative and potential yield can be reduced in near future 
(2014-2040). High temp. will increase the evapo transpiration rates, reducing the amount of water available in soil, making the planting of sugarcane increasingly difficult, which tend to be strongly reduced in drier areas Carvalhao et. al., (2015). On the other hand Marin et al. (2011) stated that climate change improve water use efficiency in sugarcane (34\%) will increase fresh stalk mass ( $24 \%$ ) in some parts of Brazil and predicted that 15-59\% higher sugarcane yield than that at current average level will be obtained in 2050 . The cane yield and sugar yield have fluctuated under the drought and tropical cyclone conditions in Fiji. Due to favorable weather a record sugar production (516529 tonnes) was obtained in 1994 but in 1997, 1998 and 2003 there were 47,50 and $43 \%$ sugarcane production was decreased than that of in 1994 due to drought environment Gawander, 2007. Sugarcane yield in Pakistan will be declined due to increased water stress conditions, arising from increasing temperature and reduction of rainy days. Sugarcane yield will decreased (10\%) by increase of $1^{\circ} \mathrm{C}$ temperature and may affect on accumulation of sucrose content Afghan (2014). Sugarcane is very sensitive to temperature, rainfall, solar radiation therefore significant effect on its production and sugar yield is expected in future. (Srivastava and Rai, 2012). radiant energy from the sun into plants fibers and sugar. During the process, the first product of photosynthesis i.e. four carbon sugar (C4) is fixed in the specialized cells of conductive tissue i.e. stem of the plant. The amount of carbon gain per day from photosynthesis is dependent on latitude and clouds covers. The previous, determines the intensities of radiation on horizontal surface and the later amount of radiation that reaches the surface. This plant thrives best under high solar insolation and temperature associates with lower latitudes (Silva et. al., 2008). Relative humidity and wind: have comparatively less control over plant, however, affect to a large extent in case of extremes. Up to 80$85 \%$ humidity and warm weather conditions favor the rapid growth of the cane. In ripening phase, a moderate humidity with limited water supply is favorable (SC 2012). Similarly, wind has no harm to plant until it reaches to a velocity capable of breakage of cane or damage to leaves. The high velocity may be harmful in initial stage of plant growth. The long duration high velocity wind will result to loss of moisture. Broadly, two different sets of climatic parameters are required in the life cycle of the plant. Long duration of bright sunshine warm season with optimum rainfall high humidity in growing phase favors rapid growth of plant as well as cane length with good yield. The ripening season which is a phase of sugar storage needs clear sky without precipitation, warm days and dry weather conditions.

\section{CONCLUSION}

It was concluded that change in environmental factors will have to be negative effect on sugarcane production. Though rise in temperature have still found low effect on decline of yield of sugarcane. But it will bring the changes in other factors like rainfall. Erratic nature of rainfall may cause to flood or drought conditions, which have to negative impact on sugarcane production. A review of various climatic factors suggests for the adaptation of modern techniques being developed at regional level in most of the sugarcane producing areas. Cultivation of sugarcane requires a thorough study of the soil and climatic conditions of the region which may vary as per the temperature of the region. 


\section{REFERENCES}

Afghan S. 2014. Climate change impact on sugar Industry of Pakistan-An overview. Conference Akram K. M. and A. Majeed 2013. Water resources situation in Pakistan: Challenges and future strategies. Water situation in Pakistan. 17 (34):33-45.

Andre Luiz de Carvalhoa, Romulo Sim Cezar Menezes, Rany ere Silva N obrega, Alexandre de Siqueira Pinto , Jean Pierre Henry Balbaud Ometto , Celso von Randow , Ang elica Giarolla. 2015. Impact of climate changes on potential sugarcane yield in Pernambuco, northeastern region of Brazil. Renewable Energy 78 :26 -34.

Annual convention-Pakistan sugarcane society technologist, PC Rawalpindi. Volume 47. Barnes AC. 1974. The Sugarcane. 2nd ed. Hill Books, London, UK. 572 p.

Begcy K., E. D. Mariano, A. Gentile, C. G. Lembke, S. M. Zingaretti, G. M. Souza, M. Menossi 2012. A novel stress-induced sugarcane gene confers tolerance to drought, salt and oxidative stress in transgenic tobacco plants. PLoS One 7:e44697.

Binbol N. L., A. A. Adebayo, E. H. Kwon-Ndung 2006. Influence of climatic factors on the growth and yield of sugar cane at Numan,Nigeria. Climate Research, 32, 247-252.

Chohan M., R.N. Panhwar, M.I. Mastoi, N. Gujar, A.H. Mari and M.A. Gadehi. 2015. relationship of physico-chemical properties and macronutrients indexing at soils of Ghora Bari area district Thatta, Sindh, Pakistan. Soil Environment. 34 (1):09-14.

Factfish, "Sugar cane, production quantity (tons)-for all countries,"2015.

Fageria N. K., C. Virupax, Baligar, C. A. Jones 2010. Growth and mineral nutrition of field crop. 3rd Ed. CRC Press, 437-456.

FAO.2015. FAO Corporatedocumentaryrepository http://www.fao.org/docrep/005/X0513E/x0513e 23.htm witnessed on $30^{\text {th }}$ April 2015.

FAO, "Report, Food and Agricultural Organization, United Nations: Economic and Social Department," The Statistical Division, FAO 2013 FAOSTAT, 2014,

FNP. 2009. AGRI ANUAL 2009 - Anurio da Agricultura Brasileria, Sâo Paulo, P497.

Gawander J. 2007. Impact of climate change on s.cane production in Fiji. WMO Bull 56 (1): 34-39.

ICAR. 2000. (Indian Council of Agricultural Res.). Handbook of Agriculture, $5^{\text {th }}$ ed., New Delhi.

GAIN. 2015. Pakistan sugar Annual. Global Agricultural Information network, USDA. Foreign Agricultural Services. GAIN Report Number:PK1518. http://www.fas.usda.gov/data/pakistan-sugarannual witnessed on 01-05-2015.

Malik, K. 1992. The irrigation. Witnessed In Cane and sugar production. $1^{\text {st }}$ Ed. Government of Punjab. Lahore. 179-190p.

Marin F. R., J. W. Jones, F. Royce, C. Suguitani, J. L. Donzelli, W. J. F. Pallone, D. S. P. Nassif 2011. Parameterization and evaluation of predictions of DSSAT/CANEGRO for Brazilian sugarcane. Agron J 103(2):304-314 
Perveen, S. Z., Malik and W. Nazif. 2010. Fertility status of vegetable growing areas of Peshawar, Pakistan. Pakistan Journal of Botany 42(3): 1871-1880.

PSMA. 2015. Annual report for the year 2015-16, Pakistan Sugar Mills Association, Sindh Zone, First floor, Modern Motors House, Beaumont road, Karachi. 17p.

Shah Z. H. and M. Arshad. 2006. Land degradation in Pakistan: A serious threat to environments and Economic sustainability. Available at: www.ecoweb.com/edi/060715.html [Accessed on: 13/12/2012].

Saleem, M. T. and E. Akhtar. 2011. CAN fertilizer in Pakistan - a boon or a bane. Farming Out Look 10(4):4.

Sc. 2012. Sugarcane. www.sugarcanecrops.com. Witnessed on January 2016.

Silva, M. A., R. A. B. Soares, M. G. A. Landell, M. P. Campana, 2007. Agronomic performance of sugarcane families in response to water stress. In: International Society of Sugarcane Technologists Congress, 26., Durban, Proceedings. Durban: ISSCT. 613-623p.

Souza A. P., M. Gaspar, E. A. Silva, E. C. Ulian, A. J. Waclawosky, M. Y. J. R. Nishiyama, R. V. Santos, M. M. Teixeira, G. M. Souza, M. S. Buckeridge 2008. Elevated CO2 increases photosynthesis, biomass and productivity, and modifies gene expression in sugarcane. Plant Cell Environ 31(8):1116-1127.

Srivastava, A. K. and M. K. Rai. 2012. Review: Sugarcane production:Impact of climate change and its mitigation. Biodiversitas 13 (4):214-227.

Trenberth K. E, P. D. Jones, P. Ambenje, R. Bojariu, D. Easterling, A. Klein Tank, D. Parker 2007. Observations: Surface and atmospheric climate change. Climate change 2007: the physical science basis. Contribution of Working Group I to the Fourth Assessment Report of the Intergovernmental Panel on Climate Change. Cambridge University Press, Cambridge

Wahab, A. 1985. Report on crop response to fertilizers and soil test data in Pakistan FAO/NFDC, Islamabad.

WWF. 2015. Sugarcane and environment, Encouraging better management practices in sugarcane production. WWF. Global Freshwater Program 3700 AA Zeist Netherland.

Zhao D., R. Yang. 2015. Climate change and sugarcane production: Potential impact and mitigation strategies. (http://dx.doi.org/10.1155/2015/547386) witnessed on 21-04-2015 Intenational Journal of Agronomy 1-10. 